\title{
Curtobacterium flaccumfaciens pv. beticola, A New Pathovar of Pathogens in Sugar Beet
}

Yong-Fang Chen and Yan-Ni Yin, Department of Plant Pathology, Nanjing Agricultural University, Nanjing 210095, China; Xiao-Mei Zhang, Zhuhai Animals and Plants Inspection Center, Guangzhou, 519000, China; and Jian-Hua Guo, Department of Plant Pathology, Nanjing Agricultural University, Nanjing 210095, China

\begin{abstract}
Chen, Y.-F., Yin, Y.-N., Zhang, X.-M., and Guo, J.-H. 2007. Curtobacterium flaccumfaciens pv. beticola, a new pathovar of pathogens in sugar beet. Plant Dis. 91:677-684.

Bacterial leaf spot of sugar beet was first discovered in 1995 in Inner Mongolia of China. The pathogen was shown to be a bacterium with properties of gram-positive bacteria: small irregular rods, lateral flagella, aerobic, and catalase-positive. The colonies of sugar beet strains produced a pale-yellow pigment. The optimum temperature for the bacteria to grow was 24 to $27^{\circ} \mathrm{C}$. The bacteria could utilize a wide range of organic compounds, including hydrolyzed casein, starch, esculin and Tween 80 , and released $\mathrm{H}_{2} \mathrm{~S}$ from cysteine, cystine, and $\mathrm{Na}_{2} \mathrm{~S}_{2} \mathrm{O}_{3} \cdot 5 \mathrm{H}_{2} \mathrm{O}$, but could not produce urease, oxidase, or indole. The cell wall peptidoglycan was based on ornithine (type B2 $\beta$ ). The predominant menaquinone was MK-9. Polar lipids contained several glycosyldiacylglycerols. The DNA G+C content of a type strain of the new pathovar, $\mathrm{T} 30^{\mathrm{T}}$, was $67.5 \%$. DNADNA homology between $\mathrm{T} 30^{\mathrm{T}}$ and Curtobacterium flaccumfaciens pv. flaccumfaciens (International Collection of Micro-Organisms from Plants, New Zealand [ICMP] 2584) was 70.1\%. The new pathovar and C. flaccumfaciens pv. flaccumfaciens had $99.9 \%$ identity in DNA sequence of 16S rRNA. Close genetic relatedness was observed for the representatives of the species Curtobacterium flaccumfaciens, but a low level of similarity between the different pathovars was found. Based on these physiological, biochemical, chemotaxonomic, phylogenetic, and genetic characteristics, we demonstrate that the pathogen represents a new pathovar of C. flaccumfaciens, for which we propose the name Curtobacterium flaccumfaciens pv. beticola pv. nov. The type strain is $\mathrm{T} 30^{\mathrm{T}}\left(=\mathrm{ATCC}\right.$ BAA- $\left.144^{\mathrm{T}}\right)$.
\end{abstract}

Additional keywords: plant pathogenic coryneform bacteria (PPCB), polyphasic analysis

In 1995, 1996, and 1998, we isolated a new pathogen from the leaves of diseased sugar beet (Beta vulgaris var. saccharifera) in Linhe City, Inner Mongolia autonomous region, China. The bacteria only damaged the leaves of sugar beet, and invaded from wounds of the leaves. The disease symptoms occurred on the leaves of sugar beet from June to October. Initially, the leaf spots were yellow and very small. They became brown with a yellow halo in a few weeks. In 1 month, the spots combined into brown patches. Finally, the entire

Corresponding author: Jian-Hua Guo

E-mail: jhguo@njau.edu.cn

Yong-Fang Chen and Yan-Ni Yin contributed equally to this study and are regarded as joint first authors.

The GenBank accession number of the 16S rRNA sequence of Curtobacterium flaccumfaciens pv. beticola is AY273208.

* The $\boldsymbol{e}$-Xtra logo stands for "electronic extra" and indicates that Figures 1 and 3 appear in color in the online edition.

Accepted for publication 17 December 2006.

doi:10.1094/PDIS-91-6-0677

(c) 2007 The American Phytopathological Society leaves dehydrated and died (Fig. 1A). The roots of diseased sugar beets were observed to be much smaller than the roots of healthy plants. The disease was found only in Linhe City, not other cities in Inner Mongolia autonomous region (S. P. Liu, personal communication). Preliminary tests suggested that the pathogen responsible for these symptoms belonged to the group of bacteria called plant pathogenic coryneform bacteria (PPCB).

PPCB are classified into six genera: Curtobacterium (5,49), Clavibacter (8), Rhodococcus (18), Rathayibacter $(7,39,54)$, and Leifsonia (15). The genus Curtobacte- rium consists of four PPCB, of which Curtobacterium flaccumfaciens pv. betae mainly causes silvering disease in red beet (Beta vulgaris var. rubra) and may be pathogenic to feed-stuff beet (Beta vulgaris var. lutea), but seldom damages sugar beet (27). The characteristic symptoms are white veins $(5,27)$; this is very different from the brown spots seen on sugar beet, as described above. In this paper, we report the results of a comparative taxonomic study of $\mathrm{T} 30^{\mathrm{T}}$ and known PPCB, including the morphological, physiological, biochemical, chemotaxonomic characteristics, 16S rRNA phylogenetical and random amplified polymorphic DNA (RAPD) analysis. Our data suggest that a new pathovar, Curtobacterium flaccumfaciens pv. beticola pv. nov., exists. The new pathogen in this study is not correlative with the strain Corynebacterium beticola, as described by Collins and Jones (4).

\section{MATERIALS AND METHODS}

Bacterial strains and their cultivation. The novel isolates were $\mathrm{T} 30^{\mathrm{T}}$, T28, and T56, which were isolated from sugar beet leaves with small spots in a field near Linhe City in July 1995, 1996, and 1998, respectively. Freshly infected leaves were washed with tap water and rinsed twice with sterilized water (SW); then individual small spots were cut into small pieces and soaked in about $20 \mu \mathrm{l}$ of SW. The resulting bacterial suspension was streaked onto a petri dish containing $20 \mathrm{ml}$ of D2 medium (26). After the plates were incubated at $28^{\circ} \mathrm{C}$ for 3 days, representative colonies were selected from each plate and further purified on the same medium. The type

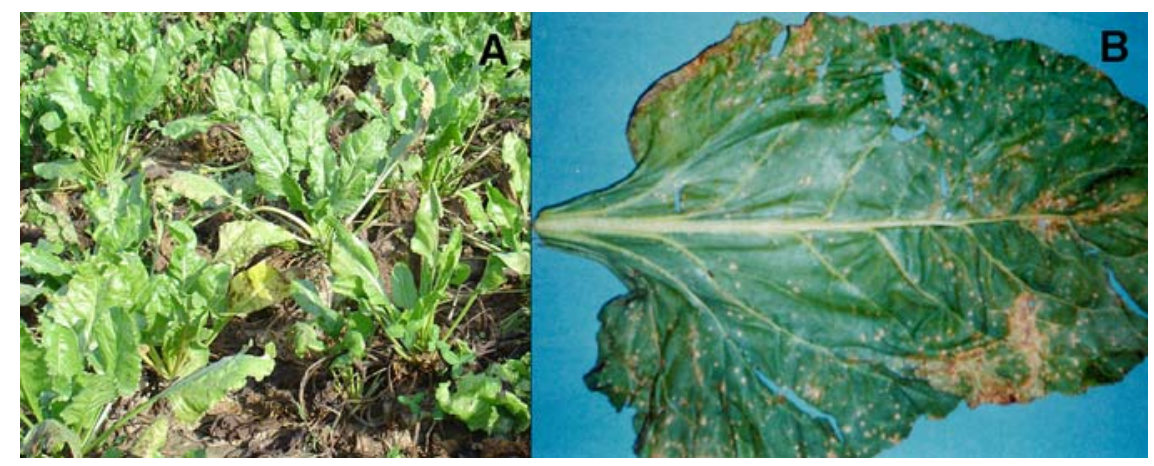

Fig. 1. Symptoms of sugar beet bacterial leaf spot caused by the new pathovar, Curtobacterium flaccumfaciens pv. beticola. A, Field symptoms; B, symptoms on leaves. 
strain $\mathrm{T} 30^{\mathrm{T}}$ was used for the following experiments.

The type and reference strains used in this comparative study are presented in Table 1. All strains were grown on D2 medium at $27^{\circ} \mathrm{C}$.

Pathogenicity test. For the pathogenicity test of $\mathrm{T}_{30}^{\mathrm{T}}$, T28, T56, and International Collection of Micro-Organisms from Plants, New Zealand (ICMP) 2594, sugar beet, red beet, tulip (Tulipa gesneriana), common poinsettia (Euphorbia pulcherrima), and bean (Phaseolus vulgaris) were used. Seedlings were transplanted into plastic pots (9 in.) containing a horticultural soil-vermiculite mixture and grown in a greenhouse at 25 to $30^{\circ} \mathrm{C}$. To prepare inoculum, bacteria were grown on D2 agar for 2 to 3 days at $27^{\circ} \mathrm{C}$, suspended in sterile distilled water, and adjusted to $10^{8}$ $\mathrm{CFU} / \mathrm{ml}$. Sugar beet and red beet at the seventh to eighth leaf stage were inoculated by using scrape and infiltration methods. Quartz was applied to the backsides of expanded leaves, then the backsides of leaves were brushed with a brush pen dipped in $10^{8} \mathrm{CFU} / \mathrm{ml}$ inoculum. A drop $(\sim 8 \mu \mathrm{l})$ of $10^{8} \mathrm{CFU} / \mathrm{ml}$ inoculum was infiltrated under the epidermis of the leaves. For beans, at the fourth to fifth leaf stage, a drop $(\sim 8 \mu \mathrm{l})$ of $10^{8} \mathrm{CFU} / \mathrm{ml}$ inoculum was infiltrated to the basal part of the stem. For common poinsettia at the fourth to fifth leaf stage, a drop $(\sim 8 \mu \mathrm{l})$ of $10^{8}$ $\mathrm{CFU} / \mathrm{ml}$ inoculum was infiltrated to the axil of the lowest leaf. For tulips, puncture the bulb with a needle dipped in $10^{8}$ $\mathrm{CFU} / \mathrm{ml}$ inoculum, then transplant into a pot and observe the onset of symptoms after 25 days. As for sugar beet, red beet, bean, and common poinsettia, observe the onset of symptoms at 7, 14, and 21 days after inoculation. Eight to 10 plants of each host were used for each strain. Three leaves were used for each plant. Inoculated plants were placed in the greenhouse at 25 to $30^{\circ} \mathrm{C}$. After microscopic examination of the fragments of inoculated sugar beet leaves (taken from the border between healthy and infected tissues), the pathogen was reisolated. The hypersensitivity (HR) test was determined using the method described by Fang (16). Each bacterial suspension $\left(\approx 10^{8} \mathrm{CFU} / \mathrm{ml}\right)$ was infiltrated into fully expanded purple jasmine (Mirabilis jalapa) leaves, and the reaction was recorded at 6 to $24 \mathrm{~h}$ after infiltration.

Physiological and biochemical characterizations. The morphology and life cycle of sugar beet strains were studied in cultures grown on D2 agar by $3 \% \mathrm{KOH}$ test (40), and observed under optical and electronic microscopy. Motility was also determined by the hanging drop method (33). The activities of catalase, gelatinase, urease, oxidase, and arginine dihydrolase were determined according to standard methods (24). Oxidase activity was determined using $1 \%(\mathrm{wt} / \mathrm{vol})$ tetramethyl- $p$ phenylenediamine solution on filter paper disks, as reported by Groth et al. (19). The production of indole, the reduction of nitrate to nitrite, and the hydrolysis of starch, esculin, Tween 80, starch hydrolysis, methyl red, Voges-Proskauer, litmus, and milk tests, sucrose deoxidize, levan production, methods of acid production, $\mathrm{H}_{2} \mathrm{~S}$ production, casein hydrolysis, acid-fast staining, $5 \% \mathrm{NaCl}$ tolerance, growth situation at $37^{\circ} \mathrm{C}$, growth factor and $\mathrm{NH}_{3}$ production were measured according to the procedures described in the literature $(16,24,43,44)$. The utilization of 32 different sugars and alcohols, leading to the formation of acid with or without gas production, was monitored according to Hugh and Leifson (25). Eleven different organic acids were used to test the ability of the culture/strain to utilize a carbon compound that was provided as a sole carbon source (13). The basal medium used for carbohydrate utilization tests was used to check the strains for their tolerance to antibiotics and growth inhibitors. All these morphological, physical, and biochemical characterization experiments were repeated in triplicate.
Chemotaxonomic characterizations. Methods used for the analysis of menaquinones were described previously by Collins et al. (6). Elucidation of the peptidoglycan structure was accomplished as described previously (30). Analysis of enantiomeric diamino acid isomer was performed according to the method reported by Sasaki et al. (39). Isolation and analysis of polar lipids were performed according to the method of Minnikin et al. (34). Sugars in whole-cell hydrolysates (1 $\mathrm{M} \mathrm{HCl}, 105^{\circ} \mathrm{C}, 30 \mathrm{~min}$ ) were analyzed by thin-layer chromatography (22).

DNA base composition and DNADNA hybridization. We isolated genomic DNA from thawed $\mathrm{T} 30^{\mathrm{T}}$ cells resuspended in TE buffer, using the technique of Bradley et al. (2). Genomic DNA G+C base composition was determined by the method of Marmur and Doty (31), replicated twice. The DNA-DNA hybridization was examined for $\mathrm{T} 30^{\mathrm{T}}$ and Curtobacterium flaccumfaciens pv. flaccumfaciens (ICMP2584) according to the method described by Martin et al. (32).

$16 S$ rRNA sequencing and phylogenetic analysis. The $16 \mathrm{~S}$ rRNA gene of $\mathrm{T} 30^{\mathrm{T}}$ was amplified by using universal rDNA primers R16F0 and CBR16R1 (28). The amplified 16S rRNA fragment was then isolated from a $1.4 \%$ agarose gel followed by purification using the crush-andsoak method, and sequenced with an ABI PRism 377XL DNA sequencer $(23,38)$. The nearly complete $16 \mathrm{~S}$ rRNA sequence was compared with sequences available from the Ribosomal Database Project and EMBL/ GenBank. Similarity values were based on a pairwise comparison of sequences. For phylogenetic analysis, the tree was constructed using the neighbor-joining method $(17,37)$ with DNAMAN (program version $6.0 ; 45,48)$. Distance matrices were processed using the same software. Tree topologies were evaluated by bootstrap analysis of the neighbor-joining tree using the 1,000 bootstrap datasets.

Table 1. A list of reference strains and the new strains isolated from sugar beet used in this study

\begin{tabular}{|c|c|c|c|}
\hline Bacterial names & Strains & Host & Origin \\
\hline Curtobacterium flaccumfaciens pv. flaccumfaciens pv. nov. & 2584 & Leguminous plants & ICMPa \\
\hline C. flaccumfaciens pv. poinsettiae & 2566 & Common poinsettia & ICMP \\
\hline C. flaccumfaciens pv. betae & 2594 & Beet (mainly red beet) & ICMP \\
\hline C. flaccumfaciens pv. oortii & 2632 & Tulip & ICMP \\
\hline C. flaccumfaciens pv. beticola & $\mathrm{T} 30^{\mathrm{T}}$ & Beet (mainly sugar beet) & Linhe City, Inner Mongolia of China, 1995 \\
\hline C. flaccumfaciens $f$. pv. beticola & $\mathrm{T} 28$ & Beet (mainly sugar beet) & Linhe City, Inner Mongolia of China, 1996 \\
\hline C. flaccumfaciens pv. beticola & T56 & Beet (mainly sugar beet) & Linhe City, Inner Mongolia of China, 1998 \\
\hline Clavibacter michiganensis subsp. michiganensis & 2550 & Solanaceous plants & ICMP \\
\hline C. michiganensis subsp. insidiosum & 2621 & Clover & ICMP \\
\hline C. michiganensis subsp. tesselarius & 7221 & Wheat & ICMP \\
\hline C. michiganensis subsp. sepedonicus & MH5 & Potato & Jiangsu, China \\
\hline C. michiganensis subsp. nebraskense & 3298 & Maize & ICMP \\
\hline Leifsonia xyli subsp. cynodontis & 8790 & Bermuda grass & ICMP \\
\hline Rathayibacter rathayi & 2574 & Cereal plants & ICMP \\
\hline R. iranicum & 3496 & Wheat (Iran) & ICMP \\
\hline R. tritici & 2626 & Wheat & ICMP \\
\hline Rhodococcus fascians & 5833 & Sweet pea & ICMP \\
\hline Arthrobacter ilicis & 2607 & American holly & ICMP \\
\hline
\end{tabular}

a International Collection of Micro-Organisms from Plants, New Zealand. 
RAPD analysis. Bacterial DNA was extracted by following a version of the hexadecyltrimethylammonium bromide (CTAB) method (11). Random primers (10 bases of oligonucleotides with 60 or $70 \% \mathrm{G}+\mathrm{C}$ content and random sequence; Table 2), dNTP, Taq DNA polymerase, and agarose (Spanish) were purchased from Takara Company. RAPD-polymerase chain reaction (PCR) was carried out in an MJ Research thermocycler (PTC 100). The reaction mixture $(25 \mu \mathrm{l})$ contained $50 \mathrm{ng}$ of template DNA, $1 \mathrm{U}$ of Taq DNA polymerase, $200 \mu \mathrm{M}$ of each dNTP, $0.64 \mathrm{mM}$ of a single primer, and $2 \mathrm{mM} \mathrm{MgCl}_{2}$ in $10 \times$ buffer $(10 \mathrm{mM}$ Tris- $\mathrm{HCl}, \mathrm{pH} 8.3 ; 50$ $\mathrm{mM} \mathrm{KCl})$. The reaction mixture was heated for $1 \mathrm{~min}$ to $94^{\circ} \mathrm{C}$ and submitted to 30 reaction cycles of $94^{\circ} \mathrm{C}$ for $30 \mathrm{~s}, 37^{\circ} \mathrm{C}$ for $90 \mathrm{~s}$, and $72^{\circ} \mathrm{C}$ for $90 \mathrm{~s}$. After the final reaction cycle, the mixture was held at $72^{\circ} \mathrm{C}$ for $5 \mathrm{~min}$ and stored at $4^{\circ} \mathrm{C}$. Amplified PCR products ( 4 to $8 \mu \mathrm{l}$ ) were separated by $1.5 \%$ agarose gel electrophoresis in $1 \times$ Tris-acetate-EDTA buffer $(40 \mathrm{mM}$ Tris-acetate, $\mathrm{pH} 8.0$, and $1 \mathrm{mM}$ EDTA) at $4 \mathrm{~V} / \mathrm{cm}$ for $5 \mathrm{~h}$. Gels were stained with ethidium bromide and photographed under UV light. DNA Ladder Plus (MBI) (100 bp) was used as marker (M) in all gels. RAPD-PCR experiments were repeated at least twice with independently prepared DNA stocks to confirm the banding patterns.

For data analysis, the genetic similarity among strains was measured according to the profiles. Each band with a different electrophoretic mobility was assigned a position number and scored as either 1 or 0 based on the presence or absence of the band, respectively, for this position. Dendrograms were constructed from the similarity coefficient data by the unweighted pair group, with the arithmetic averages clustering (UPGMA) method. The similarity value $(S x y)$ was calculated according to the following equation: [Sxy $=2 N x y /(N x+$ $N y$ )], where $N x y$ is the number of bands common to $X$ and $Y, N x$ is the total number of bands in $X$, and $N y$ is the total number of bands in $Y(9,41)$.

\section{RESULTS}

Pathogen isolation and pathogenicity test. Strains $\mathrm{T} 30^{\mathrm{T}}$, T28, and T56 formed yellow, entire margin, convex, butyrous colonies on D2 medium. Cells formed from each of the three strains with clubbed ends were frequently seen. In cultures of more than 5 days, irregular rods predominated and occurred singly, in pairs, or in ' $\mathrm{V}$ ' form, pleomorphic rod or cococci, without a rod-cococci growth cycle. This observation matches that of previous reports $(7,40)$. Cells of the bacteria were gram positive, motile, with one to three lateral flagella (Fig. 2), non-acid-fast, nonendospore-forming, and noncapsulated.

Sugar beet scraped with $\mathrm{T} 30^{\mathrm{T}}$, T28, and T56 showed the same symptoms as field observations (Fig. 1B). Red beet scraped with the three strains presented the same symptoms as with sugar beet. One week after infiltration with the three strains, yellow spots occurred on the leaves of sugar and red beets, then became brown and expanded with a chlorotic halo, but there were no silvering symptoms on red beet. Bacterial ooze was observed through microscopic examination, then isolates from the lesions were cultured on D2 medium and identified to the inoculum based on morphological characteristics previously described. Tulip, common poinsettia, and bean displayed no symptoms after inoculation with the three strains. Red beet

Table 2. Codes and sequences of the primers

\begin{tabular}{llc|llc}
\hline Primer & Sequence & \%G+C & Primer & Sequence & \% G+C \\
\hline S301 & CTGGGCACGA & 70 & S366 & CACCTTTCCC & 60 \\
S302 & TTCCGCCACC & 70 & S367 & AGCGAGCAAG & 60 \\
S303 & TGGCGCAGTG & 70 & S368 & GAACACTGGG & 60 \\
S304 & CCGCTACCGA & 70 & S369 & CCCTACCGAC & 70 \\
S305 & CCTTTCCCTC & 60 & S370 & GTGCAACGTG & 60 \\
S306 & ACGCCAGAGG & 70 & S371 & AATGCCCCAG & 60 \\
S307 & GAGCGAGGCT & 70 & S372 & TGGCCCTCAC & 70 \\
S308 & CAGGGGTGGA & 70 & S373 & GGTTGTACCC & 60 \\
S309 & GGTCTGGTTG & 60 & S374 & CCCGCTACAC & 70 \\
S310 & CCCTAGACTG & 60 & S375 & CTCCTGCCAA & 60 \\
S311 & GGAGCCTCAG & 70 & S376 & GAGCGTCGAA & 60 \\
S312 & TCGCCAGCCA & 70 & S377 & CCCAGCTGTG & 70 \\
S313 & ACGGGAGCAA & 60 & S378 & CCTAGTCGAG & 60 \\
S314 & ACAGGTGCTG & 60 & S379 & CACAGGCGGA & 70 \\
S315 & CAGACAAGCC & 60 & S380 & GTGTCGCCAG & 70 \\
S316 & CTCTGTTCGG & 60 & S381 & GGCATGACCT & 60 \\
S317 & GACACGGACC & 70 & S382 & TGGGCGTCAA & 60 \\
S318 & GACTAGGTGG & 60 & S383 & CCAGCAGCTT & 60 \\
S319 & TGGCAAGGCA & 60 & S384 & GACTGCACAC & 60 \\
S320 & CCCAGCTAGA & 60 & S385 & ACGCAGGCAC & 70 \\
S361 & CATTCGAGCC & 60 & S386 & GAGGGAAGAG & 60 \\
S362 & GTCTCCGCAA & 60 & S387 & AGGCGGGAAC & 70 \\
S363 & CCAGCTTAGG & 60 & S388 & AGCAGGTGGA & 60 \\
S364 & CCGCCCAAAC & 70 & S389 & TGCGAGAGTC & 60 \\
S365 & TCTGTCGAGG & 60 & S390 & TGGGAGATGG & 60 \\
\hline
\end{tabular}

scraped with ICMP 2594 developed typical silvery lesions, sometimes discrete and sometimes coalescent, the silvering often being most apparent at first along the veins. Three weeks after infiltration with ICMP 2594, veinal silvering was seen on the inoculated red beet, and after a further week this symptom became more intense and identical with those seen in the field (27). Sugar beet, tulip, common poinsettia, and bean displayed no symptoms after inoculation with strain ICMP 2594. HR on purple jasmine leaves occurred for all tested pathogenic Curtobacterium strains (HR for T30 ${ }^{\mathrm{T}}$ in Figure 3).

Physiological and biochemical characteristics. All of the strains- $\mathrm{T} 30^{\mathrm{T}}, \mathrm{T} 28$, and T56-were metabolically versatile, and all could utilize a variety of organic compounds, including sugars, alcohol, organic acid, amino acids, and nucleotides. They differed in the utilization of sorbose, sorbitol, and rhamnose. Only strain T56 could utilize sorbose, strain T28 could utilize sorbitol, while strain $\mathrm{T} 30^{\mathrm{T}}$ could utilize rhamnose. Levan was produced from sucrose. $\mathrm{H}_{2} \mathrm{~S}$ could be produced from cystine, cysteine, and $\mathrm{Na}_{2} \mathrm{~S}_{2} \mathrm{O}_{3}$. Both potato and soluble starch were decomposed, but not gelatin. Methyl red and Voges-

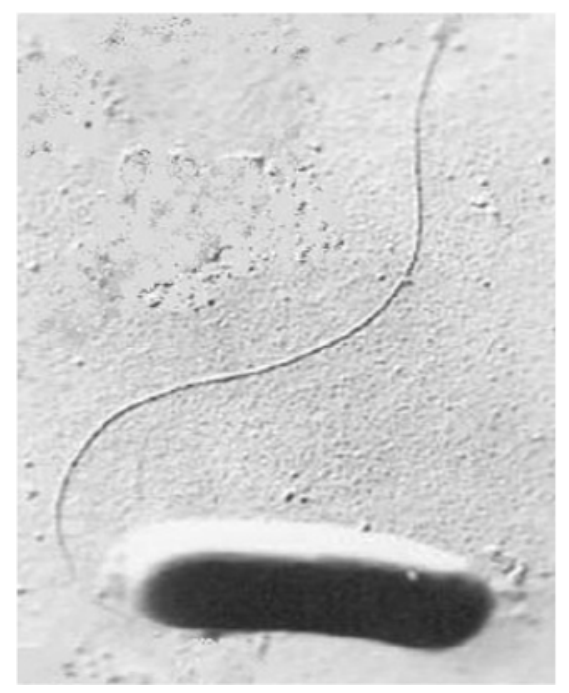

Fig. 2. Scanning electron micrograph of cells from an 18-h cultured strain $\mathrm{T} 30^{\mathrm{T}}$ grown at $28^{\circ} \mathrm{C}$ on solid D2 medium $(\times 20,000)$.

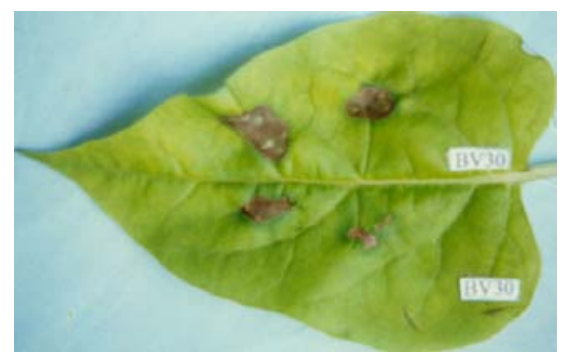

Fig. 3. Hypersensitive reaction of the strain $\mathrm{T} 30^{\mathrm{T}}(\mathrm{BV} 30=\mathrm{T} 30)$ of Curtobacterium flaccumfaciens pv. beticola on purple jasmine (Mirabilis jalapa). 
Proskauer tests were negative. Sucrose was not deoxidized. Nitrate was not reduced. Esculin, Tween 80, and Casein (not T56) were hydrolyzed. Oxidase and urease were negative, whereas catalase was positive. Acid fast staining was negative. Acid could be produced by both oxidation and fermentation. The optimal growth temperature is between 24 and $27^{\circ} \mathrm{C}$. In contrast, the bacteria did not grow at 4 or $37^{\circ} \mathrm{C}$. The strains could not grow in D2 medium that was amended with $\mathrm{NaCl}$ at $10 \%$, but could grow at $5 \%$. Indole production and $\mathrm{NH}_{3}$ production were negative. In litmus and milk tests, acid and medium peptonization occurred.

Chemotaxonomic characterization. Cell-wall analysis revealed that strain $\mathrm{T} 30^{\mathrm{T}}$ has a B2 $\beta$-type peptidoglycan based on D-ornithine, the major isoprenoid quinone MK-9, with MK-8 $\left(\mathrm{H}_{2}\right)$ and MK8 as minor components. The polar lipid pattern of $\mathrm{T} 30^{\mathrm{T}}$ is composed of PG (phosphatidyl glycerol), DPG (diphosphatidyl glycerol) and several unknown glycolipids. PI (phosphatidylinositol) and PIM (phosphatidylinositol mannose) were not detectable. $\mathrm{T} 30^{\mathrm{T}}$ contains galactose, glucose, rhamnose, and xylose, but no arabinose, mannose, and ribose in their whole cells.

DNA base composition and DNADNA hybridization. The $\mathrm{G}+\mathrm{C}$ content of $\mathrm{T} 30^{\mathrm{T}}$ is $67.5 \%$. The above characteristics are typical for the genus Curtobacterium $(3,6)$. DNA-DNA homology between strain $\mathrm{T} 30^{\mathrm{T}}$ and C. flaccumfaciens pv. flaccumfaciens (ICMP 2584) is $70.1 \%$, which is high enough to reach the threshold value of $70 \%$ that is considered for species delineation $(17,42,47)$.

Phylogenetic characterization. Nearly the complete nucleotide sequences of the 16S rRNA of strain $\mathrm{T} 30^{\mathrm{T}}(1,410 \mathrm{nt})$ were obtained. $\mathrm{T} 30^{\mathrm{T}}$ had a similarity of $99.9 \%$ to $C$. flaccumfaciens pv. flaccumfaciens, $C$. flaccumfaciens pv. betae, C. flaccumfaciens pv. oortii, and C. flaccumfaciens pv. poinsettiae in the DNA sequences of $16 \mathrm{~S}$ rRNA. $\mathrm{T}^{\mathrm{T}}$ and C. flaccumfaciens $\mathrm{pv}$. flaccumfaciens, C. flaccumfaciens pv. betae, C. flaccumfaciens pv. oortii, and $C$. flaccumfaciens pv. poinsettiae were clustered into one group, with a $92 \%$ bootstrap confidence level (Fig. 4).

RAPD fingerprinting. To identify primers that generate RAPD patterns characteristic of PPCB, we tested 50 different primers with DNA extracted from five strains (Table 2). Twenty primers (S304, S307, S309, S311, S312, S314, S315, S316, S317, S362, S367, S370, S371, S372, S373, S375, S376, S377, S380, S381) gave a total of 225 RAPD fragments, and the number of fragments scored per primer varied from 6 to 15 (Fig. 5). The sizes of the products ranged from about 0.2 to $3.0 \mathrm{~kb}$. A total of 181 of the total fragments $(80.4 \%)$ were polymorphic. The primers S316, S370, S371, and S377 amplified two common DNA fragments from Curtobacterium. The RAPD profiles that were amplified with primer S315 revealed pathovar-specific DNA fragments, permitting the identification and differentiation of the $C$. flaccumfaciens pathovars. UPGMA analysis revealed genetic diversity among all the strains, and they were divided into seven distinct groups (maximum similarity: approx. 60\%; Fig. 6). $\mathrm{T} 30^{\mathrm{T}}, \mathrm{T} 28, \mathrm{~T} 56$, and C. flaccumfaciens pv. flaccumfaciens, C. flaccumfaciens pv. betae, $C$. flaccumfaciens pv. oortii, and $C$. flaccumfaciens pv. poinsettiae were the largest group (minimum similarity value: 0.65). $\mathrm{T} 30^{\mathrm{T}}, \mathrm{T} 28$, and $\mathrm{T} 56$ displayed a higher similarity to $C$. flaccumfaciens pv. flaccumfaciens and C. flaccumfaciens pv. oortii (0.70), but a lower similarity to $C$. flaccumfaciens pv. betae (0.66). The three strains revealed the highest similarity (0.89). These results suggested that $\mathrm{T} 30^{\mathrm{T}}$ should be assigned to a novel pathovar below species $C$. flaccumfaciens.

\section{DISCUSSION}

This is the first report of bacterial leaf spot disease on sugar beet in Linhe City, Inner Mongolia autonomous region, China. Sugar beet is an important sugar plant, as well as an oil plant crop, in China and has economic importance. The disease, which is caused by $C$. flaccumfaciens pv. beticola pv. nov., has been a serious obstacle to the culture of sugar beet. In fields that are widely affected by the disease, there are sometimes total losses in sugar beet. In pathogenicity tests, the pathogen is also pathogenic to red beet, but in the field we don't find the disease (S. P. Liu, personal communication).

Genus Curtobacterium embraces six species (1), but only the species C. flaccumfaciens includes plant-pathogenic strains that are allocated to various pathovars $(3,5,10)$. The results of $\mathrm{G}+\mathrm{C}$ content of $\mathrm{T}^{3} 0^{\mathrm{T}}(67.5 \%)$ and DNA-DNA homology between $\mathrm{T} 30^{\mathrm{T}}$ and C. flaccumfaciens pv. flaccumfaciens $(70.1 \%)$, as well as the results of comparing the $16 \mathrm{~S}$ rRNA gene sequences, are powerful evidence that $\mathrm{T} 30^{\mathrm{T}}$ should be classified with species $C$. flaccumfaciens. The $16 \mathrm{~S}$ rRNA gene sequence of $\mathrm{T} 30^{\mathrm{T}}$ showed a high similarity $(99.9 \%)$ to four existing pathovars. This result also indicates high similarity among these pathovars.

Pathovar classification and nomenclature is based on the capacity of plant pathogenic bacteria to cause distinctive symptoms or by reference to their proved host range $(12,14,50,52)$. Compared with silvering disease of red beet, the symptoms of brown leaf spot without representative white veins caused by $\mathrm{T} 30^{\mathrm{T}}$ are conspicuously different. Moreover, $\mathrm{T} 30^{\mathrm{T}}$ mainly damages sugar beet, whereas $C$. flaccumfaciens pv. betae often infects red and feeding-stuff beets (27; S. P. Liu, personal communication). In applying the RAPD method, we distinguished each of five independent pathovars using just a single 10 -nt primer (S315), and found that strains of $\mathrm{T}^{3} 0^{\mathrm{T}}, \mathrm{T} 28$, and T56 exhibited $70 \%$ homology with the $C$. flaccumfaciens pv. oortii strain. Based on the differences in pathogenicity and their genetic relationships, it is necessary to allocate $\mathrm{T} 30^{\mathrm{T}}$ to a novel pathovar, C. flaccumfaciens pv. beticola. Additionally, morphological and physiological properties are both appropriate for this classification. Colonies of $\mathrm{T} 30^{\mathrm{T}}$ are more yellow and viscous on D2 medium than those of $C$. flaccumfaciens pv. betae ICMP 2594. T30 ${ }^{\mathrm{T}}$ can also be differentiated from $C$. flaccumfaciens pv. betae ICMP 2594 by acid formation from starch, utilization of acetate, $\mathrm{H}_{2} \mathrm{~S}$ production, casein hydrolysis, acid production, and litmus deoxidation. The host plant of $C$. flaccumfaciens pv. poinsettiae is common poinsettia (36), whereas that of $\mathrm{T}^{\mathrm{T}}$ is sugar beet, so we did not regard this strain as pv. poinsettiae, although physiological analysis of phenotypes significantly demonstrates that $\mathrm{T} 30^{\mathrm{T}}$ was highly similar to C. flaccumfaciens pv. poinsettiae. Recently, Young et al. (53) proposed that the authentic pathogen of American holly became a novel pathovar, Curtobacterium flaccumfaciens pv. ilicis, and Arthrobacter ilicis ICMP 2608 proved pathogenic to Ilex opaca, which is designated as the pathotype strain. In our research, A. ilicis ICMP 2607 is in a phenon that is separate from all species that all other PPCB belonged to, agreeing with the results of Young and Fletcher (51) that ICMP 2607 is not a typical strain of $C$. flaccumfaciens pv. ilicis. This result is in accordance with that of Dye et al. (12).

In many approaches to the taxonomy of plant pathogenic bacteria, analyses of chemotaxonomic and 16S rRNA sequence are a good choice $(21,29)$. Chemotaxonomic methods, such as the determination of major isoprenoid quinones, fatty-acid analysis and polar lipid patterns, play an important role in the taxonomy of a genus and species. In our study, the chemotaxonomic properties of strain $\mathrm{T} 30^{\mathrm{T}}$ correspond with those of the genus Curtobacterium. The diamino acid ornithine (Orn) is found in the peptidoglycan, which was of the B2 $\beta$ type with acetyl residues, and the major respiratory menaquinone is MK-9. 16S rRNA similarity reveals phylogenetic and evolutionary relationships among bacteria. More available data and development of software accelerate the application of the method. Meanwhile, this is necessary to respect the need for a reasonable degree of genetic stability. High 16S rRNA conformity cannot differentiate pathovars or strains (1). Comparison of FT-IR spectra (35), Biolog identification system, and methods based on genome fingerprinting (20) all prove to be useful for distinguishing pathovars. In conclusion, there is no phylogenetic standard for species, genus, 

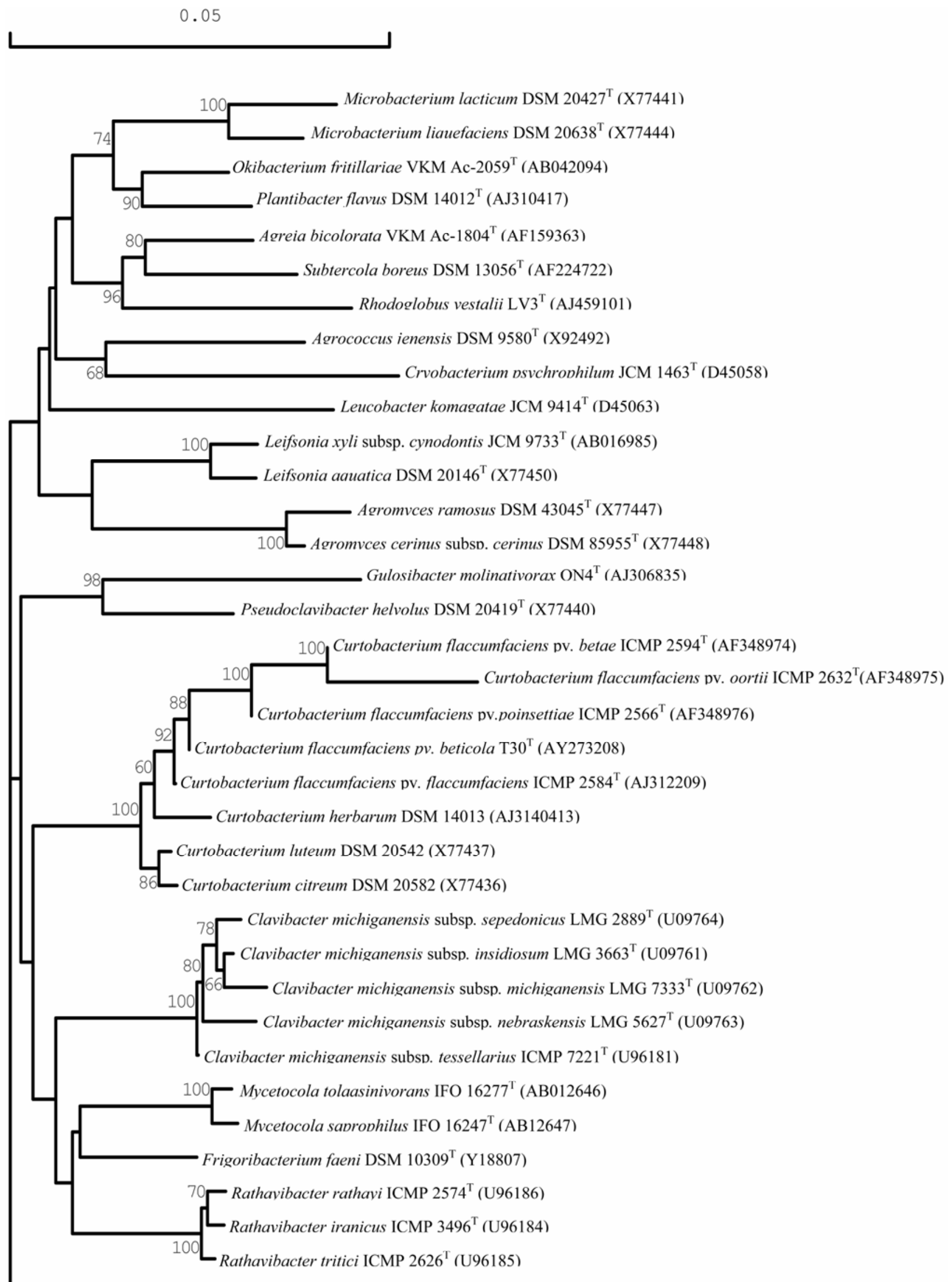

\section{Arthrobacter globiformis DSM $20124^{\mathrm{T}}$ (M23411)}

Fig. 4. A phylogenetic tree, based on the neighbor-joining method, derived from an alignment comprising $16 \mathrm{~S}$ rRNA sequences from phylogenetically related Curtobacterium spp., and genera within the family Microbacteriaceae. The 16S rRNA sequence of Arthrobacter globiformis DSM $20124^{\mathrm{T}}$ was used as an outgroup. 


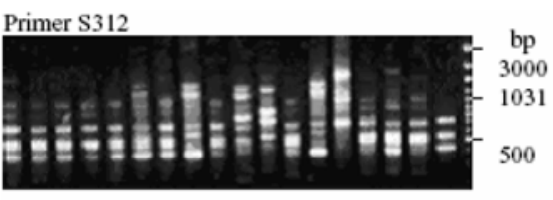

$123456789101112131415161718 \mathrm{M}$

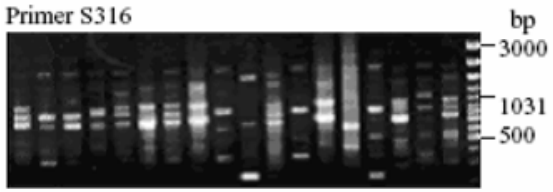

$123456789101112131415161718 \mathrm{M}$

Primer S371

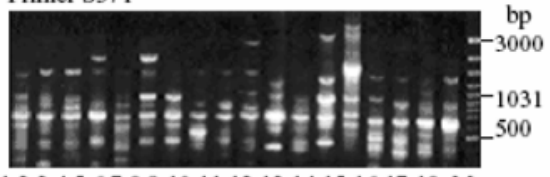

$123456789101112131415161718 \mathrm{M}$

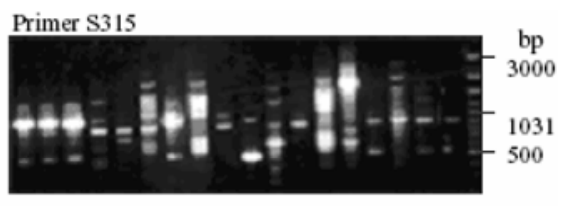

$123456789101112131415161718 \mathrm{M}$

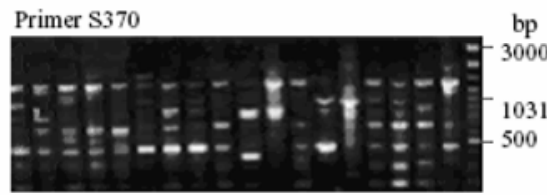

$123456789101112131415161718 \mathrm{M}$

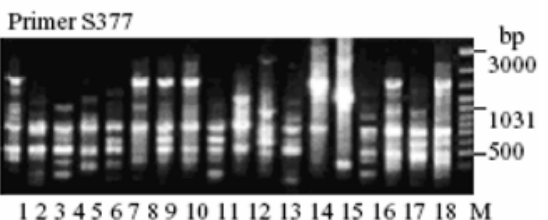

Fig. 5. Random amplified polymorphic DNA (RAPD) patterns of plant pathogenic coryneform bacteria (PPCB) strains amplified with several representative primers. Strains 1, Curtobacterium flaccumfaciens pv. beticola T28; 2, C. flaccumfaciens pv. beticola $\mathrm{T} 30^{\mathrm{T}} ; 3$, C. flaccumfaciens pv. beticola T56; 4, C. flaccumfaciens pv. poinsettiae ICMP 2566; 5, C. flaccumfaciens pv. flaccumfaciens ICMP 2584; 6, C. flaccumfaciens pv. betae ICMP 2594; 7, C. flaccumfaciens pv. oortii ICMP 2632; 8, Clavibacter michiganense subsp. michiganense ICMP 2550; 9, C. michiganense subsp. tessellarius ICMP 7221; 10, C. michiganense subsp. insidiosus ICMP 2621; 11, C. michiganense subsp. sepedonicus MH5; 12, $C$. michiganense subsp. nebraskensis ICMP 3298; 13, Rathybacter rathayi ICMP2574; $14, R$. tritici ICMP 2626; 15, R. iranicum ICMP 3496; 16, Leifsonia xyli subsp. cynodontis ICMP 8790; 17, Rhodococcus fascians ICMP 5833; 18, Arthrobacter ilicis ICMP 2607.

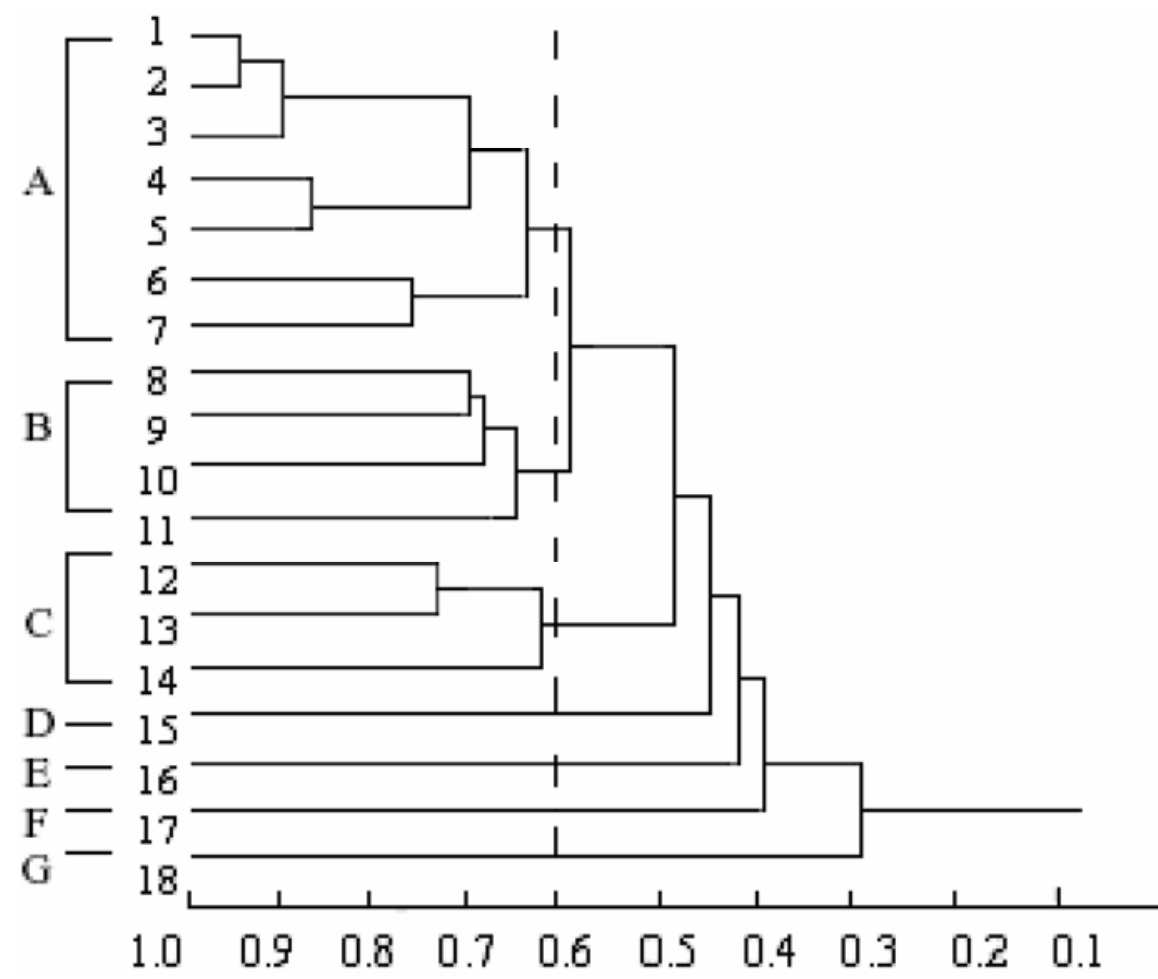

Fig. 6. Cluster dendrogram of random amplified polymorphic DNA (RAPD) in 18 plant pathogenic coryneform bacteria (PPCB) strains. Strain 1, Curtobacterium flaccumfaciens pv. beticola T56; 2, C. flaccumfaciens pv. beticola $\mathrm{T} 30^{\mathrm{T}} ; 3$, C. flaccumfaciens pv. beticola T28; 4, C. flaccumfaciens pv. flaccumfaciens ICMP 2584; 5, C. flaccumfaciens pv. oortii ICMP 2632; 6, C. flaccumfaciens pv. poinsettiae ICMP 2566; 7, C. flaccumfaciens pv. betae ICMP 2594; 8, Clavibacter michiganense subsp. tessellarius ICMP 7221; 9, Rathybacter iranicum ICMP 3496; 10, C. michiganense subsp. nebraskensis ICMP 3298; 11, Rhodococcus fascians ICMP 5833; 12, Clavibacter michiganense subsp. michiganense ICMP 2550; 13, Rathybacter rathayi ICMP2574; 14, Leifsonia xyli subsp. cynodontis ICMP 8790; 15, Arthrobacter ilicis ICMP 2607; 16, C. michiganense subsp. insidiosus ICMP 2621; 17, C. michiganense subsp. sepedonicus MH5; 18, Rathybacter tritici ICMP 2626.

or family delineation. Thus, a polyphasic approach is valuable (46).

Summarizing the results of this study and previous characterizations of the genus Curtobacterium, the bacterium isolated from leaves of diseased sugar beet reveals a high similarity to $C$. flaccumfaciens and obvious differences from other pathovars in pathogenicity. A distinct pathovar, $C$. flaccumfaciens pv. beticola pv. nov., is proposed to accommodate the new pathogen.

\section{DESCRIPTION}

Curtobacterium flaccumfaciens pv. beticola (be.ti'co.la. L. n. beta beet; L. subsp. cola dweller; M.L. n. beticola beetdweller) causes bacterial leaf spot of sugar beet and was first found in 1995 in Inner Mongolia of China.

A morphological and physiological description of the pathovar is based on type strain $\mathrm{T} 30^{\mathrm{T}}$. Cells are gram positive, strictly aerobic, non-spore-forming, noncapsulated, motile, irregularly shaped rods that sometimes form V-shapes. Colonies are pale-yellow, entire margin, convex, and butyrous. Oxidase, urease, Methyl red, and Voges-Proskauer reactions are negative, whereas catalase is positive. Aesculin, casein, Tween 80, and starch are hydrolyzed, but gelatin is not. Levan is produced from sucrose. $\mathrm{H}_{2} \mathrm{~S}$ can be produced from cystine, cysteine, and $\mathrm{Na}_{2} \mathrm{~S}_{2} \mathrm{O}_{3}$. Sucrose is not deoxidized. Nitrate is not reduced. Acid fast staining is negative. Strains produce acid from the oxidative fermentation of adonitol, cellobiose, dextrin, erythritol, fructose, galactose, glucose, glycerol, inositol, inulin, maltose, mannitol, mannose, melibiose, salicin, sucrose, rhamnose, trehalose, xylose, and $\alpha$-methyl-D-glucoside. Acid is not produced from dulcitol, ethanol, methanol, ribose, sorbitol, sorbose, or starch. Strains produce acid weakly from raffinose, lactose, arabinose, arbitol, and hepatin. Acetate, barbiturate, benzoate, butyrate, citrate, formate, glutamate, malonate, pectate, succinate, and tartrate are utilized. The optimum growth temperature is 24 to $27^{\circ} \mathrm{C}$. No growth was observed at $4^{\circ} \mathrm{C}, 37^{\circ} \mathrm{C}$, or in the presence of $10 \%$ $\mathrm{NaCl}$, although there is some growth in the presence of $5 \% \mathrm{NaCl}$. Growth factor is needed. Indole production and $\mathrm{NH}_{3}$ production were negative. In litmus and milk tests, acid and medium peptonization occurred. The diagnostic diamino acid of the peptidoglycan is D-Orn; peptidoglycan is of the B2 $\beta$ type with acetyl residues as described for the genus. The major menaquinone is MK-9. The predominant polar lipids are PG (phosphatidyl glycerol), DPG (diphosphatidyl glycerol), and several unknown glycolipids. DNA $\mathrm{G}+\mathrm{C}$ composition for the type strain is $67.5 \mathrm{~mol}$ $\%$. Type strain $\mathrm{T} 30^{\mathrm{T}}$ has been deposited in ATTC, USA (ATTC- BAA-144 ${ }^{\mathrm{T}}$ ). The EMBL accession number for the $16 \mathrm{~S}$ rRNA gene sequence is AY273208. 


\section{ACKNOWLEDGMENTS}

This research was supported by grant-in-aid for science research from the National Natural Science Foundation of China (30571211 to J.-H. Guo). The authors thank the Chinese Academy of Science for technical assistance on cell chemistry analysis and Prof. Zhong-Hua Ma for his constructive advice and critical review of this manuscript.

\section{LITERATURE CITED}

1. Behrendt, U., Ulrich, A., Schumann, P., Naumann, D., and Suzuki, K. I. 2002. Diversity of grass-associated Microbacteriaceae isolated from the phyllosphere and litter layer after mulching the sward; polyphasic characterization of Subtercola paratensis sp. nov., Curtobacterium herbarum sp. nov. and Plantibacter flavus gen. nov., sp. nov. Int. J. Syst. Evol. Microbiol. 52:1441-1454.

2. Bradley, S. G., Brownell, G. H., and Clark, J. 1973. Genetic homologies among nocardia and other actinomycetes. Can. J. Microbiol. 19:1007-1014.

3. Collins, M. D., Goodfellow, M., and Minnikin, D. E. 1980. Fatty acid, isoprenoid and polar composition in the classification of Curtobacterium and related taxa. J. Gen. Appl. Microbiol. 118:29-37.

4. Collins, M. D., and Jones, D. 1982. Taxonomic studies on Corynebacterium beticola (Abdou). J. Appl. Bacteriol. 52:229-233.

5. Collins, M. D., and Jones, D. 1983. Reclassification of Corynebacterium flaccumfaciens, Corynebacterium betae, Corynebacterium oortii and Corynebacterium poinsettiae in the genus Curtobacterium, as Curtobacterium flaccumfaciens comb. nov. J. Gen. Appl. Microbiol. 129:3545-3548

6. Collins, M. D., Pirouz, T., Goodfellow, M., and Minnikin, D. 1977. Distribution of menaquinones in actinomycetes and corynebacteria. J. Appl. Bacteriol. 48:459-470.

7. Davis, M. J. 1986. Taxonomy of plant pathogenic coryneform bacteria. Annu. Rev. Phytopathol. 24:115-140.

8. Davis, M. J., Gillaspie, A. G., Vidaver, A. K., and Harris, R. W. 1984. Clavibacter: A new genus containing some phytopathogenic coryneform bacteria, including Clavibacter xyli subsp. xyli sp. nov., subsp. nov. and Clavibacter xyli subsp. cyodontis subsp. nov., pathogens that cause ratoon stunting disease of sugarcane and Bermudagrass stunting disease. Int. J. Syst. Evol. Microbiol. 34:107-117.

9. Dice, L. R., 1945. Measures of the amount of ecologic association between species. Ecology 26:297-302.

10. Dopfer, H., Stackebrandt, E., and Fiedler, F. 1982. Nucleic acid hybridization studies on Microbacterium, Curtobacterium, Agromyces and related taxa. J. Gen. Appl. Microbiol. 128:1697-1708.

11. Doyle, J. J., and Doyle, J. L. 1987. A rapid DNA isolation procedure from small quantities of fresh leaf tissues. Phytochem. Bull. 19:1115

12. Dye, D. W., Bradbury, J. F., Goto, M., Hayward, A. C., and Lelliott, R. A. 1980. International standards for naming pathovars of phytopathogenic bacteria and a list of pathovar names and pathotype strains. Rev. Plant Pathol. 59:153-168.

13. Dye, D. W., and Kemp, W. J. 1977. A taxonomic study of plant pathogenic Corynebacterium species. N.Z. J. Agric. Res. 20:563-582.

14. Ercolani, G. L. 1987. Practical problems with the pathovar scheme in plant quarantine. Proc. Intern. Conf. Plant Pathogenic Bact. 6:786794

15. Evtushenko, L. I., Dorofeeva, L. V., Subbotin, S. A., Cole, J. R., and Tiedje, J. M. 2000. Leifsonia poae gen. nov. sp. nov., isolated from nematode galls on Poa annua, and reclassification of 'Corynebacterium aquaticum' Leifson
1962 as Leifsonia aquatica (ex Leifson 1962) gen. nov., nom. rev., comb. nov. and Clavibacter xyli Davis et al. 1984 with two subspecies as Leifsonia xyli (Davis et al. 1984) gen. nov., comb. nov. Int. J. Syst. Evol. Microbiol. 50:371-380.

16. Fang, Z. D. 1998. Methods of Plant Pathology. China Agriculture Press, Beijing. pp. 205-211.

17. Fox, G. E., Wisotzkey, J. D., and Jurtshuk, P. J. 1992. How close is close: 16S rRNA sequence identity may not be sufficient to guarantee species identity. Int. J. Syst. Bacteriol. 42:166170 .

18. Goodfellow, M. 1984. Reclassification of Corynebacterium fascians (Tilford) Dowson in the genus Rhodococcus, as Rhodococcus fascians comb. nov. Syst. Appl. Microbiol. 5:225229.

19. Groth, I., Schumann, P., Weiss, N., Martin, K., and Rainey, F. A. 1996. Agrococcus jenensis gen. nov., sp. nov., a new genus of actinomycetes with diaminobutyric acid in the cell wall. Int. J. Syst. Evol. Microbiol. 46:234-239.

20. Guimaraes, P. M., Smith, J. J., Palmano, S., and Saddler, G. S. 2003. Characterisation of Curtobacterium flaccumfaciens pathovars by AFLP, rep-PCR and pulsed-field gel electrophoresis. Eur. J. Plant Pathol. 109:817-825.

21. Han, S. K., Nedashkovskaya, O. I., Mikhailov, V. V., Kim, S. B., and Bae, K. S. 2003. Salinibacterium amurskyense gen. nov., sp. nov., a novel genus of the family Microbacteriaceae from the marine environment. Int. J. Syst. Evol. Microbiol. 53:2061-2066.

22. Hasegawa, T., Takizawa, M., and Tanida, S. 1983. A rapid analysis for chemical grouping of aerophilic actinomycetes. J. Gen. Appl. Microbiol. 29:319-322.

23. Head, I. M., Hions, W. D., Embley, T. M., McCarthy, A. J., and Saunders, J. R. 1993. The phylogeny of autotrophic ammonia-oxidizing bacteria as determined by analysis of $16 \mathrm{~S}$ ribosomal oxidizing bacteria as determined by analysis of $16 \mathrm{~S}$ ribosomal RNA gene sequences. J. Gen. Appl. Microbiol. 139:11471153.

24. Holding, A. J., and Collee, J. G. 1971. Routine biochemical tests. Method Microbiol. 6A:2-32.

25. Hugh, R., and Leifson, E. 1953. The taxonomic significance of fermentative versus oxidative metabolism of carbohydrates by various gramnegative bacteria. J. Bacteriol. 66:24-26.

26. Kado, C. I., and Heskete, M. G. 1970. Selective media for isolation of Agrobacterium, Corynebacterium, Erwinia, Pseudomonas, Xanthomonas. Phytopathology 60:969-976.

27. Keyworth, W. G., Howell, J., and Dowson, W. J. 1956. Corynebacterium betae (sp. nov.) The causal organism of silvering disease of red beet. Plant Pathol. 5:88-90.

28. Lee, I. M., Bartoszyk, I. M., GundersenEindal, D. E., and Davis, R. E. 1997. Phylogeny and classification of bacteria in the genera Clavibacter and Rathayibacter on the basis of 16S rRNA gene sequence analysis. Appl. Environ. Microbiol. 63:2631-2636.

29. Manaia, C. M., Nogales, B., Weiss, N., and Nunes, O. C. 2004. Gulosibacter molinativorax gen. nov., sp. nov., a molinatedegrading bacterium, and classification of 'Brevibacterium helvolum' DSM 20419 as Pseudoclavibacter helvolus gen. nov., sp. nov. Int. J. Syst. Evol. Microbiol. 54:783-789.

30. Männistö, M. K., Schumann, P., Rainey, F. A., Kämpfer, P., Tsitko, I., Tiirola, M. A., and Salkinoja-Salonen, M. S. 2000. Subtercola boreus gen. nov., sp. nov. and Subtercola frigoramans sp. nov., two new psychrophilic actinobacteria isolated from boreal groundwater. Int. J. Syst. Evol. Microbiol. 50:1731-1739.

31. Marmur, J., and Doty, P. 1962. Determination of the base composition of deoxyribonucleic acid from its thermal denaturation temperature. J. Mol. Biol. 5:109-118.
32. Martin, K., Schumann, P., Rainey, F. A., Schuetze, B., and Groth, I. 1997. Janibacter limosus gen. nov., sp. nov., a new actinomycete with meso-diaminopimelic acid in the cell wall. Int. J. Syst. Bacteriol. 47:529-534.

33. Meynell, G. G., and Meynell, E. 1970. Theory and Practice in Experimental Bacteriology. 2nd ed. Cambridge University Press, London.

34. Minnikin, D. E., Goodfellow, M., and Collins, M. D. 1978. Lipid composition in the classification of coagulase-positive staphylococci. Arch. Microbiol. 117:183-188.

35. Oberreuter, H. 2001. FT-IR spectroscopic identification and infraspecific diversity of coryneform bacteria in relation to $16 \mathrm{~S}$ rDNA sequence analysis. Thesis. Technische Universitat Munchen.

36. Pirone, P. P., and Bender, T. R. 1941. A new bacterial disease of poinsettiae. N.J. Agric Exp. Stn. Nursery Dis. Notes 14:13-16.

37. Saitou, N., and Nei, M. 1987. The neighborjoining method: A new method for reconstructing phylogenetic trees. Mol. Biol. Evol. 4:406425.

38. Sambrook, J., Fritsch, E. F., and Maniatis, T. 1989. Molecular Cloning: A Laboratory Manual. 2nd ed. Cold Spring Harbor Laboratory, Cold Spring Habor, NY.

39. Sasaki, J., Chijimatsu, M., and Suzuki, K. I. 1998. Taxonomic significance of 2, 4 diaminobutyric acid isomers in the cell wall peptidoglycan of actinomycetes and reclassification of Clavibacter toxicus as Rathayibacter toxicus comb. nov. Int. J. Syst. Evol. Microbiol. 48:403-410

40. Schaad, N. W., Jones, J. B., and Chun, W. 2001. Laboratory Guide for Identification of Plant Pathogenic Bacteria. 3rd ed. American Phytopathological Society, St. Paul, MN. p. 7.

41. Sorensen, T. 1948. A method of establishing groups of equal amplitude in plant sociology based on similarity of species content and its application to analyses of the vegetation on Danish commons. Vidensk Selsk. Biol. Skr. 5:1-34.

42. Stackebrandt, E., and Goebel, B. M. 1994 Taxonomic note: A place for DNA-DNA reassociation and $16 \mathrm{~S}$ rRNA sequence analysis in the present species definition in bacteriology. Int. J. Syst. Bacteriol. 44:846-849.

43. Stanier, R. Y., Palleroni, N. J., and Doudoroff, M. 1966. The aerobic pseudomonads: A taxonomic study. J. Gen. Appl. Microbiol. 43:159271.

44. Stolp, H., and Gadkari, D. 1981. Nonpathogenic members of the genus Pseudomonas. Pages 719-741 in: The Prokaryotes: A Handbook in Habitats, Isolation, and Identification of Bacteria. M. P. Starr, H. Stolp, H. G. Trupper, A. Balows, and H. G. Schlegel. eds. Springer-Verlag Press, New York.

45. Utåker, J. B., and Nes, I. F. 1998. A qualitative evaluation of the published oligonucleotides specific for the 16S rDNA gene sequences of the ammonia-oxidizing bacteria. Syst. Appl. Micrbiol. 21:72-88.

46. Vandamme, P., Pot, B., Gillis, M., De Vos, P. Kersters, K., and Swings, J. 1996. Polyphasic taxonomy, a consensus approach to bacterial systematics. Microbiology 60:407-438.

47. Wayne, L. G., Brenner, D. J., Colwell, R. R., and 9 other authors. 1987. Report of the ad hoc committee on reconciliation of approaches to bacterial systematics. Int. J. Syst. Evol. Microbiol. 37:463-464.

48. Woese, C. R., Gutell, R., Gupta, R., and Noller, H. F. 1983. Detailed analysis of the higher-order structure of $16 \mathrm{~S}$-like ribosoma ribonucleic acids. Microbiol. Rev. 47:621-669.

49. Yamada, K., and Komagata, K. 1972. Taxonomy studies on coryneform bacteria. V. Classification of coryneform bacteria. J. Gen. Appl. Microbiol. 18:417-431.

50. Young, J. M., Dye, D. W., Bradbury, J. F., 
Panagopoulos, C. G., and Robbs, C. F. 1978. The use of the term "pathovar" in the classification of plant pathogenic bacteria. Pages 359363 in: Plant Pathogenic Bacteria. Proc. 4th Int. Conf. Plant Pathogenic Bacteria, Angers. Station de Pathologie Végétale et Phytobactériologie, Institut National de la Recherche Agronomique, Beaucouzé, France.

51. Young, J. M., and Fletcher, M. J. 1997. International Collection of Micro-organisms from
Plants - Catalogue. 3rd ed. Landcare Research, Auckland, New Zealand.

52. Young, J. M., Takikawa, Y., Gardan, L., and Stead, D. E. 1992. Changing concept in the taxonomy of plant pathogenic bacteria. Annu. Rev. Phytopathol. 30:67-105.

53. Young, J. M., Watson, D. R. W., and Dye, D. W. 2004. Reconsideration of Arthrobacter ilicis (Mandel et al. 1961) Collins et al. 1982 as a plant-pathogenic species. Proposal to emend the authority and description of the species. Request for an Opinion. Int. J. Syst. Evol. Microbiol. 54:303-305.

54. Zgurskaya, H. I., Eutushenko, L. I., Akimov, V. N., and Kalakoutskli, L. V. 1993. Rathayibac ter gen. nov., including the species Rathayibacter rathayi comb. nov., Rathayibacter tritici comb. nov., Rathayibacter iranicus comb. nov. and six strains from annual grasses. Int. $\mathbf{J}$ Syst. Evol. Microbiol. 43:143-149. 